\title{
TEKNOLOGI DIGITAL MEMEDIASI DAMPAK STRATEGI BISNIS TERHADAP KINERJA UMKM DI NUSA TENGGARA BARAT
}

\author{
Armiani \\ armiani-2016@feb.unair.ac.id \\ Basuki \\ Noorlailie Suwarno \\ Fakultas Ekonomi dan Bisnis, Universitas Airlangga Surabaya
}

\begin{abstract}
The use of digital technology (e-commerce and social media) can increase the influence business strategy on the MSME performance. This study aims to examine digital technology in mediating the effect business strategy on the MSME performance. This study uses a quantitative approach with an explanatory research design, observation and questionnaire methods, with purposive sampling on halal certified and labeled food products, MSME that transact business using e-commerce and social media 2017-2019 in NTB, a sample 650 MSME with a response rate 536 MSME. The analysis tool used is SmartPLS. The findings show that digital technology partially mediates business strategy on the performance MSME. Digital technology is an intermediary variable that is able to be competitive in the global market, because MSME can do online marketing, so that their products can be recognized and can increase sales. The business strategy applied is the cost leadership strategy in terms; dominant commodity produc, production process using traditional tools, new product development, at least cooperation with resellers. Financial performance has increased sales and operating profit, non-financial performance has increased; Product quality, product quality, production target services and provide information about effectiveness, the use of digital technology in business strategies to improve the MSME performance.
\end{abstract}

Key words: business strategy, digital technology, MSME performance

\begin{abstract}
ABSTRAK
Penggunaan teknologi digital (e-commerce dan social media) dapat meningkatkan pengaruh strategi bisnis terhadap kinerja UMKM. Penelitian ini bertujuan untuk menguji teknologi digital memediasi dampak strategi bisnis terhadap kinerja UMKM. Penelitian ini menggunakan pendekatan kuantitatif dengan rancangan penelitian eksplanatory, metode observasi dan kuesioner, dengan sampling purposive pada produk pangan bersertifikat dan berlabel halal, UMKM yang bertransaksi bisnis dengan menggunakan e-commerce dan social media pada tahun 2017-2019 di NTB, sampel sebanyak 650 UMKM dengan respon rate 536 UMKM. Alat analisis yang digunakan SmartPLS. Temuan menunjukkan bahwa teknologi digital memediasi secara parsial strategi bisnis terhadap kinerja UMKM. Teknologi digital merupakan variabel perantara yang mampu berkompatitif dipasar global, dikarenakan para pelaku UMKM dapat melakukan pemasaran secara online, sehingga produknya dikenal dan dapat meningkatkan penjualan. Strategi bisnis yang diterapkan yaitu strategi cost leadership ditinjau dari; dominan produk komoditi, proses produksi menggunakan alat tradisional, kurangnya pengembangan produk baru, minimnya kerjasama dengan reseller. Kinerja keuangan mengalami peningkatan penjualan dan laba usaha, kinerja nonkeuangan mengalami peningkatan; kualitas layanan, kualitas produk, pencapaian target produksi dan memberi informasi tentang efektifitas, pemanfaatan teknologi digital pada strategi bisnis terhadap peningkatan kinerja UMKM.
\end{abstract}

Kata kunci: strategi bisnis, teknologi digital, kinerja UMKM 


\section{PENDAHULUAN}

Revolusi industri 4.0 memperkenalkan teknologi digital yang telah mengubah kehidupan manusia di berbagai bidang dan mengikis yang bersifat konvensional, salah satunya adalah dalam mencari informasi. Hal ini memicu persepsi masyarakat bahwa media digital akan mengikis media konvensional (Databooks, 2018) dan transformasi digital dianggap penting bagi pebisnis Indonesia (Databooks, 2017b). Perkembangan teknologi digital mengubah gaya hidup masyarakat pada umumnya terlihat dari perubahan perilaku masyarakat, termasuk cara pembelian barang dan jasa, keduanya dapat dilakukan secara online untuk meningkatkan pelayanan, efektivitas, kecepatan, dan dari segi keamanan memberikan kemudahan bagi pelanggan (Ramadhany dan Pritasari, 2020). Hal ini berkontribusi pada perkembangan usaha mikro kecil dan menengah (UMKM) yang memberikan informasi terkait bisnis dan transaksi komersial yang dilakukan.

Dengan berkembangnya internet, perkembangan teknologi digital telah memberikan kemudahan bagi para pelaku bisnis, sehingga tidak lagi menemui kesulitan dalam memperoleh informasi apapun yang dapat dengan mudah dan cepat tersebar luas untuk mendukung aktivitas bisnis secara global. Pengguna internet dalam bisnis mengubah fungsinya menjadi alat untuk bertukar informasi secara elektronik menjadi aplikasi strategi bisnis, seperti; pemasaran, penjualan, dan pelayanan pada pelanggan (Yuliana, 2000).

Internet juga dianggap sebagai media promosi dan penjualan yang mudah, murah, dan daya jangkauannya sangat luas. Media yang dapat menjangkau pelanggan dengan target pelanggan secara online (Mary et al., 2015). Penelitian yang dilakukan (Yuwana, 2020) membuktikan bahwa penerapan pemasaran dan transaksi secara digital memberi pengaruh positif pada keberlangsungan UMKM sehingga penggunaan teknologi digital/internet memungkinkan para pelaku UMKM melakukan pemasaran secara global dengan tujuan memaksilmalkan penjualan dan keuntungan (Basry dan Sari, 2018).

UMKM memainkan peran yang sangat krusial dalam pembangunan ekonomi di Indonesia. Dari waktu ke waktu, data inovasi dan keunikan dari berbagai produk selalu menunjukkan perkembangan yang sangat signifikan, untuk mengadopsi strategi yang berbeda/unik dari kompetitor lain agar mampu berkompatitif pada pasar global (Zainurrafiqi dan Rachmawati, 2019). Untuk berkompetitif para pelaku UMKM, harus berinovasi dan mendemonstrasikan keunikan produknya, serta mampu melakukan update teknologi terkait perkembangan bisnis. Teknologi yang dianggap mampu meningkatkan penjualan dan informasi terkait bisnis yaitu e-commerce dan social media.

E-commerce, social media, transportasi online, toko online dan lainnya berbasis internet bisnis adalah kekuatan ekonomi digital di Asia Tenggara (Databooks, 2019b). Hal tersebut terlihat dari kecenderungan masyarakat Indonesia menggunakan social media sebagai sumber informasi yang paling mudah diakses (Databooks, 2020b), dan dengan pemanfaatan $e$-commerce sebagai media pemasaran dan perdagangan (Dhewanto et al., 2018) dapat dengan mudah dijangkau oleh semua kalangan, sehingga kegiatan pengembangan pasar dan pelayanan dapat dilakukan secara maksimal.

Responden di Indonesia menunjukkan bahwa $80 \%$ penjualan dilakukan melalui social media (Databooks, 2019b), e-commerce diperkirakan mencapai 52\% (Databooks, 2017a) sehingga platform e-commerce dan social media berpotensi dan menjadi wadah untuk mempromosikan, mendorong dan meningkatkan transaksi bisnis untuk meningkatkan kinerja UMKM. Tabel 1 menunjukkan bahwa masyarakat Indonesia yang menggunakan e-commerce dan social media yang terbesar.

Dari tabel 1 menjelaskan 10 Top pengunjung terbesar, namun sesuai survei awal penelitian difokuskan pada analisis $e$ commerce (Bukalapak, Lazada, dan Shopee) 
sedangkan social media (Facebook, WhatsApp, dan Instagram), karena dominan para pelaku UMKM di NTB menggunakan platform tersebut. Platform e-commerce dan social media merupakan wadah bagi para pelaku UMKM untuk menyediakan berbagai produk (Piercy, 2009) untuk meningkatkan kinerja UMKM (Supratiwi dan Agustia, 2020).

\section{Tabel 1}

10 Top e-Commerce dan Social Media
Pengunjung Terbesar di Indonesia

Sumber: Databooks (2019a, 2020a)

Para pelaku UMKM produk pangan bersertifikat dan berlabel halal di NTB telah menggunakan pemasaran online (e-commerce dan social media), namun kendala yang dihadapi oleh para pelaku UMKM diantaranya; 1) Letak geografis, khususnya pulau Sumbawa, jaringan internet tidak terlalu bagus, 2) Minimnya kemampuan SDM yang mampu mengelola dan menggunakan teknologi digital, 3) Kurangnya staf khusus yang menangani penjualan online, 4) Akun social media dan e-commerce masih menggunakan akun gratis. Sehingga para pelaku UMKM tidak dapat memanfaatkan teknologi digital secara maksimal dalam transaksi bisnisnya.

Manfaat mengadopsi teknologi digital berbasis bisnis adalah sebagai berikut: 1) Pengurangan biaya, 2) Peningkatan fleksibilitas, 3) Pengurangan kesalahan, 4). Waktu respon lebih cepat, 5). Efisiensi biaya tenaga kerja dalam pemasaran (Afolayan et al., 2015), dan manfaat utama online business yaitu memudahkan berinteraksi dengan konsumen (Haryanto, 2014). Oleh karena itu, untuk dapat meningkatkan kinerja UMKM secara maksimal, maka para pelaku UMKM harus mampu menggunakan dan mengupdate teknologi digital untuk transaksi bisnisnya.

E-commerce merupakan pasar platform berbasis internet yang memungkinkan penjual berinteraksi dengan pelanggan dalam mengembangkan pasar yang memfasilitasi atau mempromosikan layanan konsumen (Ezzi, 2016), dan aktivitasnya dirancang khusus untuk transaksi komersial melalui penggunaan jaringan computer atau gadget dengan metode yang secara spesifik dirancang untuk tujuan menerima atau melakukan transaksi bisnis, namun pembayaran dan pendistribusiannya tidak harus dilakukan secara online (Badan Pusat Statistik, 2020). Oleh karena itu, e-commerce membuka peluang bagi UMKM untuk memasarkan dan mengembangkan jaringan bisnis secara global (Piarna dan Fathurohman, 2019) dan dapat digunakan sebagai metode alternatif; media promosi, diseminasi, informasi dan dapat memutus rantai distribusi pemasaran (Apriadi dan Saputra, 2017), bahkan dapat membantu pengendalian dan pengontrolan dalam bidang operasional perusahaan dengan baik (Yoshikuni dan Albertin, 2018).

Usaha mikro kecil dan menengah (UMKM) yang mengadopsi e-commerce dapat; 1) Meningkatkan pemahaman dan pengetahuan, 2) Meningkatkan kualitas produk dan layanan (Scupola, 2009), dengan tujuan memberikan pelayanan pada konsumen yang menggunakan e-commerce secara maksimal (Ezzi, 2016), yang berfokus pada penjualan, pemasaran/perluasan pasar, meningkatkan pendapatan dan keuntungan (Aliyu dan Tasmin, 2012). Perusahaan yang memiliki perhatian tinggi/ekstra pada konsumen akan mencapai kinerja perusahaan yang lebih tinggi dengan melakukan banyak inovasi yang memberikan nilai tambah bagi konsumennya (Hartini, 2013).

Social media merupakan metode bisnis dalam menggunakan website dan internet 
(Scupola, 2009; Ghobakhloo et al., 2011; Eze et al., 2015), yang menyediakan pasar bagi UMKM untuk membeli dan menjual barang/jasa, serta telah mencapai hasil yang positif untuk pertumbuhan, produktifitas dan kinerja perusahaan. Oleh karena itu, social media yang digunakan untuk pemasaran dapat menyediakan diantaranya; 1) Galeri produk, 2) Research target konsumen, 3) Research kebutuhan konsumen, 4) Mendata distribusi, 5) Data supplier, 6) Memantau keuntungan dari trend yang berkelanjutan. Hal inilah yang menjadi daya tarik bagi UMKM untuk memanfaatkan social media sebagai alat pemasaran modern (Fathurrohman, 2016).

Para pelaku bisnis memiliki alasan untuk memilih berjualan di social media, dikarenakan; 1) Lebih mudah untuk meraih pasar potensial, 2) Mudah digunakan, dan 3) Dapat meningkatkan jaringan dalam mendorong pertumbuhan bisnis (Databooks, 2019b). Penelitian yang dilakukan (Dewi, 2020) menunjukkan bahwa pemanfaatan teknologi yang diterapkan oleh UMKM dapat memudahkan dalam melakukan pemasaran, transaksi jual-beli, pembayaran dan pembiayaan elektronik. Hal tersebut menjadi rekomendasi bagi UMKM untuk bertahan dengan mengadopsi perdagangan secara e-commerce (Hardilawati, 2020). Sehingga teknologi digital sangat dibutuhkan dan mempermudah transaksi bisnis bagi para pelaku UMKM.

Strategi bisnis merupakan cara suatu perusahaan melakukan lebih baik, menjadi yang berbeda atau melakukan kegiatan serupa dengan cara yang berbeda, sehingga perusahaan harus menentukan model strategi yang tepat dalam rancangan yang komprehensif (Magretta, 2002). Dalam rancangan komprehensif dan terintegrasi yang diarahkan untuk mencapai tujuan perusahaan (Abdurrahman, 2015), yaitu meningkatkan kinerja keuangan dan mendorong pertumbuhan profitabilitas jangka panjang (Rajapathirana dan Hui, 2017), sehingga strategi yang tepat dapat membantu perusahaan dalam mencapai keunggulan yang kompetitif (Teeratansirikool et al., 2013). Penelitian yang dilakukan Nuvriasari et al. (2015) menunjukkan bahwa strategi bisnis (cost leadership, differentiation, and focus) berpengaruh positif terhadap kinerja UKM.

Keunggulan strategi merupakan hasil dari implementasi strategi yang memanfaatkan berbagai sumber daya yang dimiliki oleh unit bisnis (Wilantara dan Susilawati, 2016). Munculnya strategi bisnis karena; 1) Adanya tuntutan pasar, 2) Adanya persaingan, dan 3) Adanya perubahan berbagai aspek lingkungan bisnis. Perubahan tersebut mendorong perusahaan untuk membangun keunggulan agar dapat bersaing dan memaksimalkan keuntungan (Hutabarat dan Huseini, 2012; Liou dan Gao, 2011), yang dapat mendorong pertumbuhan profitabilitas jangka panjang serta keunggulan kompetitif yang berkelanjutan (Rajapathirana dan Hui, 2017).

Penelitian yang dilakukan Porter (Porter, 1980) meneliti tentang generic strategy typology (cost leadership, differentiation, and focus) terhadap kinerja yang kompetitif. Fokus dari strategi cost leadership adalah untuk mendapatkan dan meperoleh keunggulan kompetitif dengan biaya terendah untuk meningkatkan efektivitas dan efisiensi pemanfaatan sumber daya (Teeratansirikool et al., 2013), dan dalam berkompetitif para pelaku UMKM menekankan bahwa proses produksi untuk menghasilkan produk berkualitas dengan biaya yang efisien (Hadiati, 2016), sedangkan strategi differentiation mencapai keunggulan kompetitif yang menawarkan dan menyediakan pelanggan dengan produk berkualitas, unik, dan harga premium (Banker et al., 2014).

Penelitian yang dilakukan oleh (Kowo et al., 2018) menunjukkan bahwa UMKM yang menerapkan cost leadership memiliki dampak yang signifikan terhadap pengurangan biaya dan cenderung menurunkan biaya operasional, namun hasil survey awal menunjukkan bahwa para pelaku UMKM bersertifikat dan berlabel halal di NTB, dalam proses produksi masih menggunakan metode tradisional yang berarti biaya opera- 
sional masih sangat rendah, namun dibandingkan dengan produk dari luar NTB atau produk dari Pulau Jawa dengan harga yang ditawarkan masih tinggi. Menurut penelitian yang dilakukan (Anwar dan Hasnu, 2016), penerapan strategi bisnis dapat dipengaruhi oleh faktor lingkungan yang bervariasi. Hal tersebut menjadi motivasi bagi peneliti untuk lebih mengetahui strategi apakah yang diterapkan oleh para pelaku UMKM di Nusa Tenggara Barat (NTB).

Kinerja UMKM merupakan suatu indikator untuk mengukur tingkat kesuksesan dan kesehatan UMKM tersebut. Kinerja UMKM (kinerja keuangan dan kinerja non keuangan) digunakan sebagai media pengukuran yang objektif untuk menggambarkan efektifitas penggunaan asset dalam operasional untuk meningkatkan keuntungan dari pengembangan bisnis (Tarute dan Gatautis, 2014; Almor dan Hashai, 2004), pencapaian target penjualan, penambahan aset (Wen et al., 2018), dan menjaga keberlangsungan bisnisnya tersebut (Eniola dan Entebang, 2015). Hal tersebut bertujuan untuk mencapai dan mengimplementasikan strategi, yaitu untuk memperoleh sinergi antara berbagai fungsi dan unit bisnis yang ada (Abdurrahman, 2015). Untuk menjadi industry yang kuat dan memiliki kemampuan dinamis dan berdayasaing, maka industri harus meningkatkan perolehan informasi agar produknya sesuai dengan kebutuhan pelanggan (Anjaningrum, 2021).

Teori yang melatarbelakangi penelitian ini adalah Resources Based View (RBV). RBV merupakan teori yang mendasari daya saing yang berkaitan dengan faktor internal dalam organisasi (Wernerfelt, 1984; Barney, 1991; Barney et al., 2001; Wang, 2013; Olsen dan Safdar, 2014). Teori RBV menjelaskan bahwa perusahaan secara fundamental heterogen dalam hal kapabilitas dan sumber daya internal (Lockett et al., 2008). RBV mengidentifikasi bahwa faktor kunci dalam menentukan keunggulan kompetitif adalah kebutuhan organisasi untuk memproduksi, menerapkan, memanfaatkan, memilihara, mempertahankan, merumuskan, dan mengembangkan strategi untuk mencapai keunggulan kompatitif (Haseeb et al., 2019).

Teori RBV dapat diterapkan pada penelitian UMKM, karena sudut pandang terkait RBV menjelaskan bahwa pelaku usaha merupakan kombinasi sumber daya yang unik dan berbeda yang memiliki peran dalam organisasi (Dhewanto et al., 2018) serta dapat mengidentifikasi kemampuan UKM, meliputi; 1) Kemampuan inovasi, 2) Kapasitas produksi, dan 3) Keterampilan manajemen pemasaran (Barney et al., 2001). Hasil penelitian yang dilakukan (Suardhika, 2012) menunjukkan bahwa kombinasi sumberdaya strategis dan orientasi kewirausahaan dapat memperbaiki atau meningkatkan posisi kompatitif, yang mampu menyelaraskan dinamika lingkungan bisnis yang dihadapi dan dapat meningkatkan kinerja UKM. Namun jika UKM tidak menerapkan strategi bersaing yang dilandasi pengintegrasian sumber daya strategi dan orientasi kewirausahaan, maka dinamika lingkungan yang dihadapi dapat menghambat atau menurunkan kinerja UKM.

Dalam penelitian ini, para pelaku UMKM di NTB menerapkan berbagai kebijakan terkait kapasitas produksi, dan sering melakukan inovasi (inovasi produksi maupun inovasi kemasan) untuk mempertahankan dan memenuhi kebutuhan para pelanggan, serta memanfaatkan dan mengaplikasikan teknologi digital untuk transaksi bisnisnya (melakukan penjualan- pembelian secara online) hal tersebut dilakukan untuk memenuhi kebutuhan para pelanggan dan untuk mencapai keunggulan kompatitif.

Produk halal kini menjadi tren konsumsi di seluruh dunia, baik di negara Muslim maupun nonmuslim. Sesuai tuntunan agama Islam yang terdapat dalam AlQuran dan Hadis yang mewajibkan bagi umat Muslim mengkonsumsi makanan dan minuman yang halal, serta mengharuskan dan memastikan produk yang dijual memenuhi persyaratan halal dari LPOM-MUI (Zailani et al., 2015). Indonesia merupakan salah satu Negara dengan mayoritas pendu- 
duk muslim terbesar di dunia dan mengharuskan pemerintah melindungi warga negaranya atas produk yang dikonsumsi (Sayekti, 2014). Hal tersebut diterbitkannya Undang-undang No. 33 Tahun 2014 tentang jaminan produk halal. NTB mayoritas muslim (Islam sebesar 96,78\%) dengan berkonsentrasi pada program pariwisata halal, yang didukung oleh produk pangan bersertifikat dan berlabel halal sesuai peraturan daerah Provinsi NTB No. 2 Tahun 2016 tentang pariwisata halal.

Data pada tahun 2018 menunjukkan bahwa sebanyak 648.573 UMKM dan UMKM produk pangan yang bersertifikat dan berlabel halal sebanyak 650 UMKM $(6,85 \%)$, artinya masih minimnya UMKM produk pangan yang bersertifikat dan berlabel halal di NTB. Padahal potensi produk pangan yang bersertifikat halal cukup berkompatitif, sesuai hasil survey dan wawancara awal dengan para pelaku UMKM di NTB, menyatakan bahwa hasil produksi telah memasuki pasar domestik (Bali, Sulawesi, Jawa, dan Sumatra, Maluku), maupun internasional (Malaysia, Singapura, Korea, Japan dan Arab Saudi). Hal inilah yang menjadi motivasi peneliti untuk peneliti pada UMKM yang bersertifikat dan berlabel halal.

Penelitian ini fokus pada UMKM produk pangan bersertifikat dan berlabel halal di NTB, dengan alasan bahwa UMKM yang sudah memiliki sertifikat dan berlabel halal adalah UMKM yang sudah beroperasi lebih dari dua tahun, memiliki hasil produksi yang berkelanjutan, dan SDM yang lebih baik, serta produk yang mampu berkopatitif dipasar global. Hal tersebut menandakan bahwa, para pelaku UMKM dianggap memiliki strategi yang diterapkan, teknologi digital yang digunakan, dan pengetahuan untuk meningkatkan kinerja UMKM.

Berpijak pada uraian sebelumnya, maka tujuan dari penelitian ini adalah menguji peran mediasi teknologi digital (e-commerce dan social media) pada pengaruh strategi bisnis terhadap kinerja UMKM produk pangan bersertifikat dan berlabel halal di Nusa Tenggara Barat (NTB).

\section{TINJAUAN TEORETIS}

\section{Teori Resource Based View (RBV)}

Teori yang melatar belakangi penelitian ini adalah Resource Based View (RBV) di tinjau dari manajemen strategi yang meliputi keunggulan kompetitif (Barney et al., 2001). Keunggulan kompetitif sering digunakan sebagai alat strategi, yang dapat menghalangi perusahaan lain memasuki pasar dengan produk yang memiliki keunggulan yang serupa. Keunggulan kompetitif berdasarkan RBV merunjuk pada keunggulan kompetitif berkelanjutan (Fitriati, 2015).

Strategi dalam mempertahankan keunggulan kompetitif berkelanjutan, yaitu dengan memilih strategi bisnis yang tepat, menggunakan teknologi digital untuk melakukan berbagai inovasi guna meningkatkan kinerja UMKM, sehingga dapat digunakan secara optimal dalam berbagai aktivitas perusahaan dan pasar yang berbeda (Wernerfelt, 1984).

Perspektif RBV memberikan wawasan penting, dengan menyoroti keterkaitan ekonomi dan teknologi informasi, yang lebih relevan dengan era ekonomi modern (Theo dan Tim, 2005; Burvill et al., 2018), jadi RBV memiliki implikasi penting pada teknologi digital untuk memberikan hal baru dalam berbagai ide yang dikembangkan, dan menginspirasi berbagai hal, untuk memanfaatkan potensi RBV terkait dengan kemampuan strategi pemasaran (Barney et al., 2001) yang menggunakan e-commerce dan social media, hal tersebut berlaku pada pasar yang cepat berubah dengan kemampuan dinamis, pasar yang stabil, dan sumber daya yang berkemampuan (Barney, 1991), serta dapat menjelaskan isu ekonomi yang berbeda (Barney et al., 2001).

RBV membantu memperdalam pemahaman dan mengkombinasikan sumber daya untuk diterapkan dalam menghasilkan keunggulan kompetitif berkelanjutan (Alonso dan Bressan, 2016). Kapabilitas Sumber daya teknologi digital (internal) 
menentukan strategi yang diterapkan pada lingkungan bisnis eksternal, dan kapabilitas perusahaan memungkinkan untuk menambah pelanggan, mengembangkan produk baru atau memperluas pasar (Madhani, 2010).

Banyak model yang dikembangkan untuk menjelaskan, bagaimana RBV mempengaruhi realisasi keunggulan kompetitif yang dapat diterapkan pada UMKM. Selama ini, fakta membuktikan bahwa UMKM telah berkontribusi secara signifikan bagi pembangunan ekonomi suatu bangsa, fenomena ini terjadi baik di negara berkembang maupun di negara maju (Fitriati, 2015).

Teknologi digital yang dirancang dengan baik terkait penggunaannya, yang pada gilirannya memiliki beberapa efek pada kinerja (Theo dan Tim, 2005), dengan mengidentifikasi pentingnya tiga kemampuan dasar pada UKM yaitu; (1), kemampuan inovatif, (2) Kemampuan produksi, (3) Kemampuan manajemen marketing, (Barney et al., 2001) sehingga RBV dapat diterapkan pada penelitian UMKM dengan variabel teknologi digital sebagai mediasi pada pengaruh strategi bisnis terhadap kinerja UMKM.

Penelitian ini dimulai dengan tinjauan literatur dari beberapa variabel yang diteliti seperti: Strategi bisnis terhadap kinerja UMKM, strategi bisnis terhadap teknologi digital (e-commerce dan social media), dan strategi bisnis dimediasi oleh teknologi digital (e-commerce dan social media) terhadap kinerja UMKM. Hal ini diasumsi bahwa semua variabel yang diteliti tersebut merupakan hal yang penting bagi para pelaku UMKM agar mampu bersaing dan berkompetisi pada pasar global.

\section{Peran Strategi Bisnis terhadap UMKM}

Berdasarkan data dari Dinas koperasi dan UMKM Provinsi NTB periode sampai 2018 sebanyak 648.573 UMKM dengan jumlah penduduk sebanyak 5.013.687 jiwa, artinya penduduk NTB yang menjadi pelaku UMKM sebesar 12,94\%. Hal tersebut menunjukkan bahwa peran UMKM dalam keberlanjutan dan penompang hidup sangat penting. Perbedaan yang paling signifikan antara UMKM pada negara berkembang dengan negara maju yaitu ditinjau dari perspektif tenaga kerja (sumber pendapatan bagi kelompok miskin), distribusi pendapatan (pengurangan kemiskinan), dan pembangunan ekonomi pedesaan. Namun, dilihat dari sumbangan terhadap pembentukan PDB dan ekspor non-migas, khususnya produk-produk manufaktur, yaitu inovasi dan pengembangan teknologi masih relatif rendah (Tambunan, 2017).

Sebuah organisasi dikatakan memiliki keunggulan kompetitif jika mampu menawarkan produk berkualitas dengan harga yang lebih rendah dari pesaingnya (Aziz dan Samad, 2016). Strategi bisnis UMKM didasarkan pada fleksibilitas, kreativitas, kedekatan dengan para pelanggan, dan cepat merespon pasar yang berfluktuasi. Hadirnya konsep 4.0 berpotensi menyediakan lebih detail tentang informasi proses dan pengendalian yang diinginkan (Moeuf et al., 2018).

Dalam menghadapi revolusi industri 4.0 seorang pebisnis perlu memiliki berbagai jenis keterampilan, sesuai penelitian yang dilakukan (Agustina, 2019) diantaranya: 1) Keterampilan informasi, media, dan teknologi, 2) Keterampilan belajar dan berinovasi, 3) Keterampilan dalam hidup dan belajar, 4) Kemampuan dalam berkomunikasi yang efektif.

Tantangan UMKM di era transformasi digital ekonomi adalah rendahnya kemampuan SDM menghadapi metode perdagangan yang secara tradisional dan konvensional menjadi teknologi digital atau online bisnis. Era digital merupakan era keterbukaan baik dari segi transaksi, hak cipta, maupun bidang keuangan. Hal tersebut, mengharuskan pemerintah menciptakan lingkungan yang mendukung programnya, melindungi dan membuat regulasi untuk para pelaku UMKM, serta infrastruktur teknologi khususnya di daerah pedesaan.

Hambatan utama UMKM dalam mengadopsi teknologi digital seseuai penelitian yang dilakukan (Eze et al., 2015) 
yaitu sebagai berikut: 1) Kurangnya pendanaan, 2) Kurangnya pasokan listrik, 3) Kurangnya SDM yang terlatih, 4) Kurangnya pemeliharaan fasilitas teknologi, 5) Kurangnya kebijakan teknologi yang koheren.

Teknologi digital akan selalu dinamis, bergerak menuju perbaikan yang memberikan kemudahan atau manfaat kepada penggunanya, dan keberadaan jejaring sosial cukup menarik perhatian penggunanya (Purwanto, 2011). Pemanfaatan teknologi informasi dan transaksi elektronik bertujuan untuk mengembangkan perdagangan dan ekonomi nasional untuk meningkatkan kesejahteraan masyarakat, dan teknologi berperan penting dalam strategi perkembangan perusahaan untuk kerlanjutan usaha (Dhewanto et al., 2018).

Penelitian (Chi et al., 2016), menemukan hubungan langsung antara strategi bisnis terhadap kinerja perusahaan. Secara umum strategi berkontribusi positif terhadap kinerja keuangan, namun hanya strategi differentiation yang meningkatkan kinerja secara langsung melalui strategy alignment (Yuliansyah et al., 2016). Penggunaan strategic information systems (SIS) yang efektif dapat mencapai orientasi strategis dan beberapa manfaat dalam mempengaruhi kinerja perusahaan (Yoshikuni dan Albertin, 2018). Berdasarkan uraian di atas dapat diajukan hipotesis pertama yaitu:

$\mathrm{H}_{1}$ : Strategi bisnis terhadap kinerja UMKM

\section{Peran Teknologi Digital terhadap UMKM}

Dalam skala global, kemampuan teknologi informasi berbasis sumber daya terhadap kinerja perusahaan dapat memberikan layanan yang cepat, terjangkau, dan memperbaharui (update) informasi lebih cepat dari para pesaing (Zhang dan Tansuhaj, 2007), sehingga teknologi digital berpengaruh terhadap kinerja perusahaan (Yunis et al., 2018).

Dampak globalisasi yang didukung oleh kemajuan teknologi, telah mengubah sistem bisnis pada dunia kontemporer, dengan tujuan untuk bertahan dan mencapai hasil yang maksimal. Oleh karena itu, penting untuk mempersiapkan kompetisi guna memanfaatkan peluang bisnis yang dinamis (Bulak dan Turkyilmaz, 2014). Banyak perusahaan mulai menggunakan dan memanfaatkan sumberdaya digital untuk merumuskan serta mengimplementasikan strategi bisnis digital (Chi et al., 2016), dengan tujuan suatu perusahaan dapat menekan biaya, meningkatkan kinerja perusahaan, dan mencapai keberlanjutan bisnis yang kompetitif (Bulak dan Turkyilmaz, 2014). Berdasarkan uraian di atas dapat diajukan hipotesis kedua yaitu:

$\mathrm{H}_{2}$ : Teknologi digital terhadap kinerja UMKM

\section{Strategi Bisnis dan Teknologi Digital terhadap UMKM}

Strategi bisnis dan teknologi informasi merupakan dua variabel yang saling mendukung untuk keberlansungan bisnis dan kinerja organisasi (Ilmudeen dan Malik, 2017). Kontribusi teknologi digital terhadap akses berbasis internet dapat meningkatan penjualan dan profitabilitas (Raymond dan Bergeron, 2008). Era digital dengan menggunakan social media menjadi pilihan untuk meningkatkan pelayanan bagi pelanggan yang dapat mengakses internet (Kim et al., 2017), dan perkembangan digital dikonsepkan sebagai solusi yang mendukung digitalisasi bisnis (Khin dan Ho, 2018).

Bagi investor dan manajer organisasi, penting untuk mempertimbangkan perencanaan dan penerapan strategi, dengan mengadopsi teknologi informasi dalam meningkatkan provitabilitas usaha (ValdezJuárez et al., 2018). Kemampuan organisasi untuk memperoleh keunggulan kompetitif meliputi; Cost leadership atau differentiation dapat meningkatkan kinerja jangka panjang dalam struktur industry (Porter, 1980), dan evaluasi kinerja berdampak positif terhadap kinerja perusahaan (kinerja keuangan dan kinerja non keuangan). Perusahaan menggunakan strategi cost leadership dan differentiation dalam rangka meningkatkan kinerja perusahaan (Teeratansirikool et al., 2013) yang berarti cost leadership mempe- 
ngaruhi kinerja organisasi (Hilman dan Kaliappen, 2014).

Strategi kompetitif berpengaruh positif pada kinerja UKM dan strategi kompetitif memiliki hubungan yang signifikan pada pangsa pasar perusahaan. Oleh karena itu, penting bagi UKM mempelajari perkembangan informasi yang update untuk menyenangkan dan memuaskan pelanggan dalam meningkatkan omset penjualan bisnis UKM (Kowo et al., 2018) dengan menerapkan strategi bisnis yang tepat untuk keberlanjutan bisnisnya.

Mengadopsi teknologi digital dapat memberikan manfaat diantaranya; pengurangan biaya, fleksibilitas, pengurangan kesalahan, waktu respon lebih cepat, dan efisiensi biaya tenaga kerja dalam pemasaran (Afolayan et al., 2015). Layanan konsumen dengan menggunakan e-commerce dapat mengembangkan pasar UKM (Ezzi, 2016), yang mampu bersaing jika diselarasin dengan mengadopsi strategic information systems (SIS), karena dapat membantu perusahaan melakukan pengontrolan dengan baik, bahkan dalam lingkungan operasional perusahaan (Yoshikuni dan Albertin, 2018). Sehingga UKM dapat juga mengadopsi berbagai kebijakan untuk meningkatkan kinerja perusahaan dan transformasi digitalisasi dengan melakukan perkembangan yang update dalam model bisnis (Bouwman et al., 2019). Teknologi berpengaruh terhadap kinerja (Johannessen et al., 1999; Evangelista et al., 2012). Berdasarkan uraian di atas dapat diajukan hipotesis ketiga yaitu;

$\mathrm{H}_{3}$ : Teknologi digital memediasi pengaruh strategi bisnis terhadap kinerja UMKM

\section{METODE PENELITIAN}

\section{Rerangka Penelitian}

Gambar 1 menjelaskan rerangka penelitian dengan gambar variabel yang diteliti yaitu; 1). Strategi bisnis mempengaruhi kinerja UMKM, 2). Strategi bisnis mempengaruhi teknologi digital, dan 3). Strategi bisnis mempengaruhi kinerja UMKM dimediasi oleh teknologi digital. Pengajuan hipotesis secara teoritis didukung dengan perkembangan penelitian terdahulu dan dikombinasi dengan kejadian dilapangan (survey awal penelitian). Perkembangan hipotesis tersebut berasal dari rumusan masalah yang diajukan dan dilakukan analisis untuk membuktikan hasil temuan dalam penelitian ini dengan penelitian terdahulu.

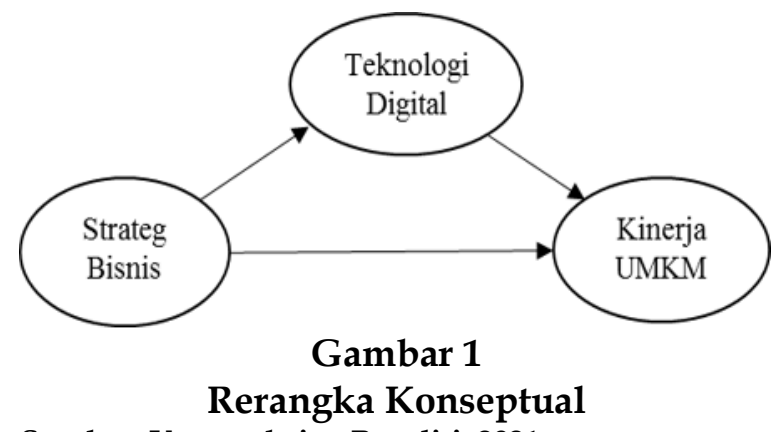

Sumber: Konstruksian Peneliti, 2021

\section{Jenis Penelitian}

Penelitian ini menggunakan pendekatan kuantitatif dengan rancangan penelitian eksplanatory.

\section{Metedo Pengumpulan Data}

Penelitian ini berasal dari data primer. Metode wawancara dan observasi serta kuesioner digunakan untuk memperoleh data dan informasi langsung kepada para pelaku UMKM produk pangan yang bersertifikat dan berlabel halal di NTB.

\section{Skala Pengukuran}

Skala pengukuran variabel dengan menggunakan skala ordinal dengan teknik pengukuran skala likert 5 (lima) poin, nilai poin mengindikasi sikap dari responden terhadap variabel yang diteliti (strategi bisnis, teknologi digital, dan kinerja UMKM) yang digunakan yaitu; (5) Sangat sering, (4) Sering, (3) Kadang-kadang, (2) Jarang, (1) Tidak pernah (Sugiyono, 2018).

\section{Populasi dan Sampel}

Populasi dalam penelitian ini adalah UMKM industry formal di NTB yaitu sebanyak 9.493 UMKM. Metode pengambi- 
lan sampel menggunakan sampling purposive, dengan kriteria: 1) UMKM produk pangan yang bersertifikat dan berlabel halal, 2) UMKM yang bertransaksi bisnis menggunakan e-commerce dan social media, dan 3) Tahun pengamatan 2017-2019, sehingga sampel sebanyak 650 UMKM.

Kuesioner disebarkan dengan mendatangi langsung (observasi/survey) kepada responden yang jarak lokasi dapat terjangkau oleh peneliti, dan melakukan wawancara via telephone pada responden yang jarak lokasi tidak terjangkau oleh peneliti, serta melakukan focus group discussion (FGD) dibeberapa Kabupaten. Kuesioner yang kembali dan yang dapat dihubungi via telephone sebesar 536 UMKM atau respon rate sebesar $82,46 \%$

\section{Teknik Analisis Data}

Alat analisis yang digunakan adalah structural equation modeling (SEM) dengan software SmartPLS versi 3.0. Proses pemodelan SEM SmartPLS meliputi dua tahap dasar, yaitu verifikasi model pengukuran dan pengujian model struktur.

\section{ANALISIS DAN PEMBAHASAN}

\section{Gambaran Umum Subjek Penelitian}

Penelitian dilakukan di Nusa Tenggara Barat (NTB). NTB terdiri dari dua pulau yaitu pulau Lombok (Kota Mataram, Kab Lombok Barat, Kab Lombok Tengah, Lobok Timur, dan Kab Lombok Utara) dan pulau Sumbawa (Kota Bima, Kab Bima, Kab Dompu, Kab Sumbawa, dan Kab Sumbawa Barat). Fokus penelitian pada UMKM prduk pangan bersertifikat dan berlabel halal dengan alasan: 1) UMKM yang sudah memiliki sertifikat halal adalah UMKM yang sudah beroperasi sekurang-kurangnya dua tahun, 2) Hasil produksi sudah kontinu, dan 3) SDM lebih baik.

Hal tersebut dianggap bahwa para pelaku UMKM memiliki kemampuan dan pengetahuan terkait pemanfaatan teknologi digital (e-commerce dan social media) dalam menetapkan strategi bisnis yang tepat untuk meningkatkan kinerja UMKM.
Para pelaku UMKM dalam penelitian ini yaitu;

1) Jumlah responden perempuan 392 orang (73\%) disbanding responden laki-laki 144 orang (27\%). Ditinjau dari usia 16-35 tahun sebanyak 104 orang $(20 \%)$, usia $36-$ 55 tahun sebanyak 409 (76\%), dan usia diatas 55 tahun sebanyak 23 orang (4\%) artinya para pelaku UMKM merupakan para ibu-ibu dengan berstatus dominan sudah menikah, sehingga mereka lebih realita dan fokus dalam membantu perekonomian keluarga, menjadikan UMKM sebagai usaha berkelanjutan dan beberapa orang meneruskan usaha turun-temurun dari orang tua atau keluarganya,

2) Ditinjau dari jenjang pendidikan, SLTP sebanyak 35 orang (7\%), SMU sebanyak 171 orang (32\%), Diploma sebanyak 84 orang (16\%), Strata satu (S1) sebanyak 240 orang $(45 \%)$, dan pasca sarjana (S2) sebanyak 6 orang (1\%) sehingga dominan para UMKM jenjang pendidikan pada SMU dan S1, artinya para pelaku UMKM dengan tingkat pendidikan yang sudah bagus, dianggap mampu mengelola usaha secara maksimal dengan menggunakan teknologi digital untuk berdaya saing dan mampu mempetahankan keberlanjutan usahanya dengan beberapa jumlah produk dalam satu UMKM.

3) Ditinjau dari lama usaha yaitu 1-5 tahun sebanyak 309 orang $(57,6 \%)$, 6-10 tahun sebanyak 212 orang $(39,5 \%)$ dan diatas 10 tahun sebanyak 15 orang $(2,8 \%)$. Ditinjau dari lama penggunaan teknologi (gadget) adalah 1-5 tahun sebanyak 417 orang (77,8\%), 6-10 tahun sebanyak 118 orang $(22 \%)$ dan diatas 10 tahun sebanyak 1 orang $(0,2 \%)$. Hal tersebut menunjukkan bahwa lama usaha berbanding lurus dengan lama menggunakan gadget/ handphone, artinya para pelaku UMKM mulai bisnisnya dengan menggunakan teknologi (gadget/handphone), dalam berkomunikasi untuk kelangsungan dan kelancaran transaksi bisnisnya. 
4) Jumlah produk yang di pasarkan oleh para pelaku UMKM yaitu; pada 1-5 produk berjumlah 484 UMKM $(90,3 \%)$, pada 6-10 produk berjumlah 46 UMKM $(8,58 \%)$, dan diatas 10 produk berjumlah 6 UMKM (1,12\%). Hal tersebut menunjukkan bahwa satu UMKM namun dapat memasarkan beberapa produk, sehingga mampu meningkatkan pendapatan dan laba usahanya (meningkatkan kinerja UMKM).

5) Jumlah produk yang bersertifikat halal yaitu; pada 1-2 produk berjumlah 526 UMKM $(98,13 \%)$, 3-4 produk berjumlah 9 UMKM $(1,68 \%)$, dan diatas 4 produk perjumlah 1 UMKM (0,19\%). Jumlah produk yang berlabel halal yaitu; pada 1-5 produk berjumlah 485 UMKM $(90,49 \%)$, 6-10 produk berjumlah 45 UMKM $(8,40)$, dan diatas 10 produk berjumlah 6 UMKM (1,12\%). Hal tersebut menunjukkan bahwa satu sertifikat halal dapat memproduksi dan memasarkan beberapa produk berlabel halal, ditinjau dari bahanbaku yang digunakan masih sama.

\section{Analisis Inferensial}

Pengujian validitas dan reliabilitas konstruk, uji R-Square $\left(\mathrm{R}^{2}\right)$, uji goodness of fit model (GoF), dan evaluasi Q2 dalam penelitian tabel 2.

Tabel 2 uji validitas dan reliabilitas pada penelitian ini menunjukkan semua variabel valid dan reliabel artinya dapat diterima dan dilanjutkan ke pengujian selanjutnya.

Tabel 3, 4, dan 5 berdasarkan hitungan nilai GoF sebesar 0,461 (kuat) dan 0,233 (lemah), dan hitungan nilai dari Q-Square (Q2) sebesar 0,833 dan 0,653 yang artinya mendekati 1 (jika nilai lebih besar 0 dan menekati 1), sehingga pengujian dalam penelitian ini layak dilanjutkan untuk pengujian hipotesis.

Tabel 2

Hasil Uji Validitas dan Reliabilitas

\begin{tabular}{lcccc}
\hline \multicolumn{1}{c}{ Variabel } & AVE & $\begin{array}{c}\text { Alpha } \\
\text { Cronbach's }\end{array}$ & $\begin{array}{c}\text { Composite } \\
\text { Reliability (CR) }\end{array}$ & Keterangan \\
\hline \hline Cost Leadership__ifferentiation & 0.538 & 0.857 & 0.891 & Diterima \\
E_Commerce & 0.635 & 0.718 & 0.836 & Diterima \\
Kinerja UMKM & 0.547 & 0.892 & 0.914 & Diterima \\
Kinerja Keuangan & 0.939 & 0.936 & 0.969 & Diterima \\
Kinerja Nonkeuangan & 0.535 & 0.877 & 0.901 & Diterima \\
Strategi Bisnis & 0.538 & 0.857 & 0.890 & Diterima \\
Social Media & 0.832 & 0.899 & 0.937 & Diterima \\
Teknologi Digital & 0.587 & 0.897 & 0.918 & Diterima \\
\hline
\end{tabular}

Sumber: Output SmartPLS versi 3.0

Tabel 3

Hasil Uji R-Square

\begin{tabular}{llll}
\hline Variabel & R2 & R2 Adjusted & Keterangan \\
\hline \hline Cost Leadership__ifferentiation & 0.999 & 0.999 & Kuat \\
E-Commerce & 0.520 & 0.520 & Moderat \\
Kinerja UMKM & 0.389 & 0.386 & Lemah \\
Kinerja Keuangan & 0.652 & 0.652 & Moderat \\
Kinerja Nonkeuangan & 0.916 & 0.916 & Kuat \\
Social Media & 0.842 & 0.842 & Kuat \\
Teknologi digital & 0.432 & 0.431 & Lemah \\
\hline
\end{tabular}

Sumber: Output SmartPLS versi 3.0. 
Tabel 4

Nilai $\mathbf{R}^{2}$ dan Communalities (Moderat)

\begin{tabular}{lcc}
\hline \multicolumn{1}{c}{ Variabel } & $\mathbf{R}^{\mathbf{2}}$ & Communalities \\
\hline \hline E-Commerce & 0.520 & 0.635 \\
Kinerja & 0.652 & 0.939 \\
Keuangan & & \\
Rata-rata & 0.586 & 0.787 \\
\hline
\end{tabular}

Sumber: Output SmartPLS versi 3.0.

Nilai GoF dan Q2 Q2 = 1-(1-R12) (1-R12)

Moderat $\quad$ Q2 $=1-(1-0.520)(1-0.652)$

GoF $=\sqrt{\left(\operatorname{Comm} x R^{2}\right)} \quad \mathrm{Q} 2=1-(0.480)(0.348)$

GoF $=\sqrt{(0.787 \times 0.586)} \quad Q 2=1-0.1670$

$\mathrm{GoF}=0,461$

Tabel 5

Nilai $\mathbf{R}^{2}$ dan Communalities (Lemah)

\begin{tabular}{lcl}
\hline \multicolumn{1}{c}{ Variabel } & R2 & Communalities \\
\hline \hline Kinerja UMKM & 0.389 & 0.547 \\
$\begin{array}{l}\text { Teknologi } \\
\text { digital }\end{array}$ & 0.432 & 0.587 \\
Rata-rata & 0.411 & 0.567
\end{tabular}

Sumber: Output SmartPLS versi 3.0.

Nilai GoF dan Q2 Q2 = 1-(1-R12) (1-R12)

Lemah $\quad$ Q2 $=1-(1-0.389)(1-0.432)$

GoF $=\sqrt{\left(\operatorname{Comm} \times R^{2}\right)} \quad \mathrm{Q} 2=1-(0.611)(0.568)$

GoF $=\sqrt{(0.567 \times 0.411)} \quad \mathrm{Q} 2=1-0.3470$

$\mathrm{GoF}=0,233$

$\mathrm{Q} 2=0.653$

\section{Analisis Koefisien Jalur}

Tabel 6 dan 7 menunjukkan bahwa semua variabel (outer model maupun inner model) mempunyai nilai koefisien dengan arah positif, artinya strategi bisnis lebih efektif dalam penentuan sasaran pasar dan harga jual, jika penggunaan teknologi digital (ecommerce dan social media) dilakukan secara

maksimal dan tepat sasaran, sehingga dapat meningkatkan kinerja UMKM.

\section{Pengujian Hipotesis}

Tahap awal yang dilakukan adalah dengan pengujian pengaruh langsung (direct effect) strategi bisnis terhadap kinerja UMKM tanpa melibatkan variabel mediasi teknologi digital (e-commerce dan social media), hasil dapat dilihat pada tabel 8 .

Berdasarkan tabel 8, bahwa strategi bisnis berpengaruh positif terhadap kinerja UMKM, artinya penentuan strategi bisnis yang diterapkan oleh para pelaku UMKM dengan tepat dan sesuai dengan produk yang dihasilkan dapat meningkatkan kinerja UMKM. Hasil diatas menunjukkan terpenuhinya syarat ini dan dapat dilanjutkan ke pengujian selanjutnya, yaitu pengujian strategi bisnis berpengaruh terhadap kinerja UMKM yang dimediasi oleh teknologi digital, dapat dilihat pada gambar 2 dan tabel 9.

Berdasarkan tabel 8 menunjukkan bahwa koefisien jalur strategi bisnis $\rightarrow$ kinerja UMKM signifikan sebesar 0,572, sedangkan tabel 7 koefisien jalur strategi bisnis $\rightarrow$ kinerja UMKM signifikan sebesar 0,359 . Hasil tersebut menunjukkan bahwa terkait efek mediasi strategi bisnis terhadap kinerja UMKM dengan koefisien jalur strategi bisnis $\rightarrow$ kinerja UMKM sebesar 0,573 menjadi 0,359 , yang artinya bahwa hipotesis dari efek mediasi dalam penelitian ini diterima.

Tabel 6

Pengujian Koefisien Jalur Outer Model

\begin{tabular}{lll}
\hline & Hubungan & Koefisien Jalur \\
\hline \hline Strategi Bisnis & Cost Leadership_Differentiation & 1.000 \\
Teknologi Digital & E_Commerce & 0.721 \\
Teknologi Digital & Social Media & 0.918 \\
Kinerja UMKM & Kinerja Keuangan & 0.808 \\
Kinerja UMKM & Kinerja NonKeuangan & 0.957 \\
\hline
\end{tabular}

Sumber: Output SmartPLS versi 3.0. 
312 Ekuitas: Jurnal Ekonomi dan Keuangan - Volume 3, Nomor 5, Septamber 2021 : 300 - 320

\section{Tabel 7}

Pengujian Koefisien Jalur Inner Model

\begin{tabular}{lll}
\hline \multicolumn{2}{c}{ Hubungan } & Koefisien Jalur \\
\hline \hline Strategi Bisnis & Teknologi Digital & 0.657 \\
Strategi Bisnis & Kinerja UMKM & 0.359 \\
Teknologi Digital & Kinerja UMKM & 0.325 \\
Sumber: Output SmartPLS versi 3.0. &
\end{tabular}

\section{Tabel 8}

Pengaruh Strategi Bisnis terhadap Kinerja UMKM

\begin{tabular}{cccccc}
\hline Variable & $\begin{array}{c}\text { Koefisien } \\
\text { jalur }\end{array}$ & $\begin{array}{c}\text { Deviasi } \\
\text { standar }\end{array}$ & $\begin{array}{c}\text { Statistik } \\
\mathbf{t}\end{array}$ & $\begin{array}{c}\text { P - } \\
\text { values }\end{array}$ & Deskripsi \\
\hline Strategi Bisnis $\rightarrow$ Kinerja UMKM & 0.572 & 0.030 & 18.820 & 0.000 & Signifikan \\
\hline Strategris
\end{tabular}

Sumber: Output SmartPLS versi 3.0.

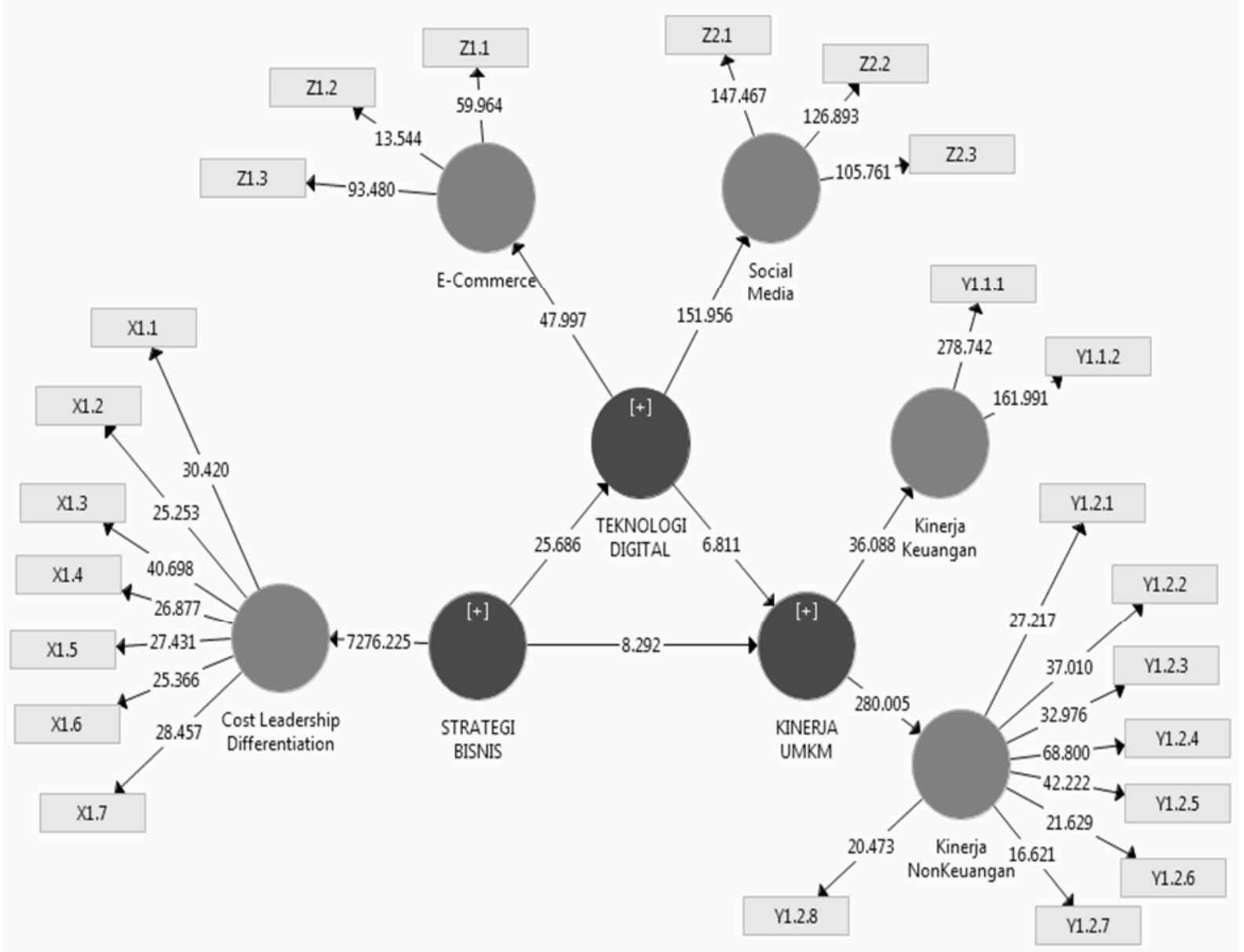

Gambar 2

Hasil Analisis model structural

Sumber: Data Primer diolah, 2021 
Table 9

Pengaruh Strategi Bisnis terhadap Kinerja UMKM yang Dimediasi Teknologi Digital

\begin{tabular}{|c|c|c|c|c|c|}
\hline Variabel & $\begin{array}{c}\text { Koefisien } \\
\text { jalur }\end{array}$ & $\begin{array}{l}\text { Deviasi } \\
\text { standar }\end{array}$ & $\begin{array}{c}\text { Statistik } \\
\mathbf{t}\end{array}$ & $\begin{array}{c}\text { P- } \\
\text { values }\end{array}$ & Deskripsi \\
\hline \multicolumn{6}{|c|}{ Pengaruh langsung (Direct effects) } \\
\hline $\begin{array}{l}1 \text { Strategi Bisnis } \rightarrow \text { Kinerja } \\
\text { UMKM }\end{array}$ & 0.359 & 0.043 & 8.292 & 0.000 & Signifikan \\
\hline $2 \begin{array}{l}\text { Strategi Bisnis } \rightarrow \\
\text { Teknologi Digital }\end{array}$ & 0.657 & 0.026 & 25.686 & 0.000 & Signifikan \\
\hline $\begin{array}{ll}3 & \text { Teknologi Digital } \rightarrow \\
& \text { Kinerja UMKM }\end{array}$ & 0.325 & 0.048 & 6.811 & 0.000 & Signifikan \\
\hline \multicolumn{6}{|c|}{ Pengaruh tidak langsung (Indirect effects) } \\
\hline $\begin{array}{ll}1 & \text { Strategi Bisnis } \rightarrow \\
& \text { Teknologi Digital } \rightarrow \\
& \text { Kinerja UMKM }\end{array}$ & 0.214 & 0.034 & 6.219 & 0.000 & Signifikan \\
\hline Pengaruh total (Total effects & & & & & \\
\hline $\begin{array}{l}1 \text { Strategi Bisnis } \rightarrow \text { Kinerja } \\
\text { UMKM }\end{array}$ & 0.573 & 0.031 & 18.733 & 0.000 & Signifikan \\
\hline
\end{tabular}

Sumber: Output SmartPLS versi 3.0.

Pengujian hipotesis variabel teknologi digital memediasi strategi bisnis terhadap kinerja UMKM, dengan pengujian pengaruh langsung (direct effect) dan tidak langsung (indirect effect) pada strategi bisnis terhadap kinerja UMKM. Hal tersebut dapat dilihat pada gambar 2 dan tabel 9.

\section{Pengaruh Langsung}

Strategi bisnis berpengaruh pada kinerja UMKM

Berdasarkan Gambar 2 dan Tabel 9 menunjukkan hasil pengujian strategi bisnis berpengaruh positif terhadap Kinerja UMKM. Pada tingkat level signifikan 5\% sebesar 8,292 > 1,96) dan P Values 0,000. Nilai koefisien jalur 0,359 yang menunjukkan bahwa hubungan strategi bisnis terhadap Kinerja UMKM bernilai positif. Nilai standar deviasi 0,043 menunjukkan bahwa data yang dikumpulkan memiliki variasi yang kecil (homogen) artinya hipotesis ini diterima.

\section{Strategi bisnis berpengaruh pada teknologi digital}

Berdasarkan Gambar 2 dan Tabel 9 menunjukkan hasil pengujian strategi bisnis berpengaruh positif terhadap teknologi digi- tal. Pada tingkat level signifikan $5 \%$ sebesar $25,686>1.96$ dan P Values 0,000. Nilai koefisien jalur 0,657 yang menunjukkan bahwa hubungan strategi bisnis terhadap teknologi digital bernilai positif. Nilai standar deviasi 0,026 menunjukkan bahwa data yang dikumpulkan memiliki variasi yang kecil (homogen) artinya hipotesis ini diterima.

Teknologi digital berpengaruh pada kinerja UMKM

Berdasarkan Gambar 2 dan Tabel 9 menunjukkan hasil pengujian teknologi digital berpengaruh positif terhadap Kinerja UMKM. Pada tingkat level signifikan 5\% sebesar 6,811 > 1,96 dan P Values 0,000. Nilai koefisien jalur 0,325 yang menunjukkan bahwa hubungan teknologi digital terhadap Kinerja UMKM bernilai positif. Nilai standar deviasi 0,048 menunjukkan bahwa data yang dikumpulkan memiliki variasi yang kecil (homogen) artinya hipotesis ini diterima.

\section{Pengaruh tidak langsung}

Tabel 9 menunjukkan hasil pengujian pengaruh tidak langsung (indirect effect) antar variabel strategi bisnis terhadap kinerja UMKM yang di mediasi oleh teknologi digi- 
tal. Pada tingkat level signifikan $5 \%$ sebesar $6,219>1,96$ dan $\mathrm{P}$ Values 0,000. Nilai koefisien jalur 0,214 yang menunjukkan bahwa hubungan strategi bisnis terhadap Kinerja UMKM yang di mediasi oleh teknologi digital. Hal tersebut menunjukkan bahwa semakin tinggi atau ketatnya penerapan dan penetapan strategi bisnis melalui penggunaan teknologi digital secara maksimal dan tepat sasaran maka berdampak pada peningkatan Kinerja perusahaan. Nilai standar deviasi 0,034 menunjukkan bahwa data yang dikumpulkan memiliki variasi yang kecil (homogen), artinya hipotesis ini diterima.

\section{Pengaruh Total}

Berdasarkan Tabel 8 dan 9 menunjukkan bahwa koefisien jalur strategi bisnis mempengaruhi kinerja UMKM signifikan dan positif sebesar 0,572. Sedangkan Tabel 9 koefisien jalur strategi bisnis mempengaruhi kinerja UMKM signifikan dan positif sebesar 0,359 . Hasil tersebut menunjukkan bahwa terkait efek mediasi strategi bisnis terhadap kinerja UMKM dengan pengaruh total koefisien jalur strategi bisnis mempengaruhi kinerja UMKM sebesar 0,573, yang artinya bahwa hipotesis dari efek mediasi ditinjau dari model partial mediation dalam penelitian ini diterima.

Hasil direct effects, indirect effects dan total effects dari penelitian ini, dapat disimpulkan bahwa semua variabel yang diteliti memiliki nilai yang signifikan dan pengaruh positif. Sehingga hipotesis 1 yang diajukan diterima.

Proses analisis selanjutnya adalah dengan metode Variance Accounted For (VAF) atas pengaruh strategi bisnis terhadap kinerja UMKM yang dimediasi oleh teknologi digital, dapat dijelaskan bahwa strategi bisnis berpengaruh langsung dan signifikan terhadap kinerja perusahaan, sehingga memenuhi kriteria untuk dilanjutkan pada tahap perhitungan nilai VAF. Efek mediasi metode VAF dengan kriteria; tidak terjadi mediasi $(0 \%-19 \%)$, partial mediation $(20 \%$ $80 \%)$, dan full mediation ( $81 \%-100 \%)$ yaitu;
Teknologi Digital memediasi pengaruh strategi bisnis terhadap kinerja UMKM.

$\mathrm{VAF}=\frac{\text { Pengaruh tidak langsung }}{\text { Pengaruh total }} \times 100 \%$

$\mathrm{VAF}=\frac{0,214}{0,573} \times 100 \%$

$\mathrm{VAF}=37,35 \%$

Perhitungan VAF menunjukkan bahwa hasil mencapai 37,35\% bahwa teknologi digital memediasi secara partial mediation pada pengaruh strategi bisnis terhadap kinerja UMKM, artinya teknologi digital bukan menjadi satu-satunya variabel yang mampu memediasi pengaruh strategi bisnis terhadap kinerja UMKM, namun masih ada variabel lain dan menjadi peluang bagi peneliti selanjutnya. Sehingga dalam penelitian ini, menunjukkan bahwa teknologi digital mampu memediasi pengaruh strategi bisnis terhadap kinerja UMKM yang membuktikan bahwa hipotesis diterima.

\section{Pembahasan}

Hasil penelitian ini menunjukkan bahwa teknologi digital (e-commerce dan social media) memediasi secara partial mediation strategi bisnis terhadap kinerja UMKM. Teknologi digital (e-commerce dan social media) dua variabel yang berkolaborasi menjadi perantara (mediasi) agar mampu berkompatitif di pasar global, hasil penelitian ini didukung oleh penelitian yang dilakukan (Raymond dan Bergeron, 2008), (Kim et al., 2017), (Khin dan Ho, 2018), (ValdezJuárez et al., 2018), karena para pelaku UMKM dapat melakukan pemasaran secara online, dengan e-commerce (Bukalapak, Lazada, dan Shopee), dan social media (Facebook, Instagram, WhatsApp).

Hasil analisis para pelaku UMKM yang memanfaatkan teknologi digital dengan bekerjasama dengan e-commerce (Bukalapak, Lazada, dan Shopee) terkait pemasaran dan penjualan produk, menunjukkan bahwa dominan para pelaku UMKM produk pangan bersertifikat dan berlabel halal di 
NTB, masih minimnya penggunaan ecommerce, karena: 1) Minimnya pengetahuan tentang transaksi bisnis e-commerce, 2) Pelatihan dari platform belum merata, 3) Dominan para pelaku masih menggunakan akun gratis dari platform e-commerce, 4) Belum seriusnya para pelaku UMKM melakukan transaksi penjualan dengan menggunakan e-commerce, 5) Ketidak sabaran dalam melayani pelanggan secara online, dan 6) Masih adanya pelaku UMKM yang tidak memiliki rekening bank dan sms banking untuk transaksi bisnisnya.

Selain itu, para pelaku UMKM yang menggunakan dan kerjasama dengan $e$ commerce berbeda-beda disetiap daerah, karena tergantung dari platform narasumber para pelaku UMKM yang mengikuti pelatihan tersebut.

Hasil analisis para pelaku UMKM yang memanfaatkan social media menunjukkan bahwa para pelaku UMKM produk pangan bersertifikat dan berlabel halal di NTB, sudah sangat familiar dengan penggunaan facebook dan WhatsApp, dikarenakan lebih mudah, gratis dan sasaran pasarnya masih lokal (orang-orang yang dikenal). Sedangkan Instagram, selain tidak familiar, mereka juga, tidak terlalu memahami tentang proses upload dan transaksi bisnisnya.

Para pelaku UMKM sering menggunakan e-commerce dan social media sebagai forum untuk memasarkan produknya, walaupun akun yang digunakan masih secara gratis, belum dimanfaatkan secara maksimal, sehingga pemasaran belum optimal.

Strategi bisnis yang diadopsi oleh para pelaku UMKM merupakan strategi cost leadership karena ditinjau dari perspektif; 1). Proses produksinya masih menggunakan alat tradisional, 2). Kurangnya pengembangan produk baru, 3). Kurangnya kerjasama dengan reseller, 4). Kurangnya kerjasama dengan distributor dan 5). Dominan produknya masih produk domestik.

Guna memuaskan keinginan dan kepuasan pelanggannya, para pelaku UMKM menerapkan cost leadership dengan tujuan agar mampu bersaing secara kompetitif didukung oleh penelitian yang dilakukan (Yoshikuni dan Albertin, 2018). Namun ada sebagian yang tidak memiliki percaya diri dan minimnya tingkat SDM terkait teknologi digital, sehingga jarang memasarkan produknya secara online (penjualan tradisional), karena tidak ada pegawai khusus yang menangani transaksi online, dan para pelaku UMKM sudah merasa puas dengan hasil yang diperoleh. Hal tersebut berdampak pada tingkat penjualan produknya.

Hasil penelitian ini berdampak pada peningkatan kinerja UMKM (kinerja keuangan maupun kinerja non keuangan). Dari sisi penjualan, kinerja keuangan meningkat 18,5\%-69,2\%, laba meningkat sebesar 22,8\%$65.7 \%$, dan kinerja non keuangan meningkat ditinjau dari; kualitas pelayanan, kualitas produk, dan pencapaian target produksi.

Hasil analisis tersebut menunjukkan bahwa para pelaku UMKM bersertifikat dan berlabel halal di NTB memiliki keunggulan lebih dominan dalam meningkatkan kualitas produk, kualitas pelayanan, dan pencapaian target produksi. Hal tersebut dikarenakan produk yang dihasilkan para pelaku UMKM sering melakukan inovasi produk dengan mencoba ide-ide baru dalam desain produk, menggunakan sistem one day work focus untuk satu jenis atau satu varians produk, dan sering menerima orderan/ pesanan secara online (social media dan e-commerce), serta via telephone. UMKM yang bersertifikat dan berlabel halal dari pemerintah mendapatkan prioritas untuk mengikuti pelatihan dan pameran yang diselenggarakan oleh pemerintah daerah/ setempat. Sehingga para palaku UMKM yang bersertifikat dan berlabel halal mampu bersaing pada pasar global (online dan offline). Hal tersebut membuktikan bahwa ecommerce dan social media mampu memediasi strategi bisnis terhadap kinerja UMKM.

\section{SIMPULAN DAN SARAN SIMPULAN}

Hasil penelitian ini membuktikan bahwa peran teknologi digital mediasi (e- 
commerce dan social media) pada pengaruh strategi bisnis terhadap kinerja UMKM produk pangan bersertifikat dan berlabel halal di NTB, dapat disimpulkan sebagai berikut;

Strategi bisnis yang diadopsi oleh para pelaku UMKM produk pangan bersertifikat dan berlabel halal yaitu strategi cost leadership karena ditinjau dari perspektif; proses produksi masih menggunakan alat tradisional, kurangnya pengembangan produk baru, kurangnya kerjasama dengan reseller, kurangnya kerjasama dengan distributor dan dominan produknya masih produk domestik.

Kinerja UMKM (baik kinerja keuangan maupun kinerja non keuangan) mengalami peningkatan. Kinerja keuangan ditinjau dari peningkatan penjualan sebesar 18,5\%-69,2\%, peningkatan laba sebesar 22,8\%-65,7\%, sedangkan kinerja non keuangan mengalami peningkatan ditinjau dari; kualitas layanan, kualitas produk, dan pencapaian target produksi.

Para pelaku UMKM menggunakan platform E-commerce (Bukalapak, Lazada, dan Shopee) dan social media (Facebook, Instagram, WhatsApp).

E-commerce dan social media dua variabel yang berkolaborasi menjadi perantara (mediasi) agar mampu berkompatitif di pasar global, karena para pelaku UMKM dapat melakukan pemasaran secara online, dengan e-commerce, dan social media, hal tersebut membuktikan bahwa e-commerce dan social media mampu memediasi strategi bisnis terhadap kinerja UMKM.

Penelitian ini memberikan kontribusi pada bidang akuntansi manajemen berbasis strategi dan pemasaran (pemasaran dengan menggunakan teknologi digital), dan berkontribusi pada para pelaku UMKM produk pangan bersertifikat dan berlabel halal di NTB yaitu dalam pengadopsian strategi yang tepat, pemanfaatan teknologi digital untuk meningkatkan kinerja UMKM.

\section{SARAN}

Penelitian selanjutnya diharapkan untuk mengkaji lebih banyak lagi platform dari e-commerce dan social media yang ada di Indonesia dan menambah variabel lain serta analisis yang mendalam dengan menggunakan metode kualitatif dan mixed method.

\section{DAFTAR PUSTAKA}

Abdurrahman, N. H. 2015. Manajemen Strategi Pemasaran. Pustaka Setia Bandung Indonesia. Bandung.

Afolayan, A., E. Plant, G. R. T. White, P. Jones, dan P. BeynonDavies. 2015. Innovation Technology Usege in SMEs in a Developing Economy. Strategic Change 24: 483-498.

Agustina, T. S. 2019. Kewirausahaan di Era Revolusi Industri 4.0. Mitra Wacana Media. Jakarta Indonesia.

Aliyu, A. A. dan R. B. H. J. Tasmin. 2012. The Impact of Information and Communication Technology on Banks Performance and Customer Service Delivery in the Banking Industry. International Journal of Finance, Insurance and Risk Management 2(1): 80-90.

Almor, T. dan N. Hashai. 2004. The Competitive Advantage and Strategic Configuration of Knowledge-Intensive, Small- and Medium-sized Multinationals: a Modified Resource-based View. Journal of International Management 10: 479-500.

Alonso, A. D. dan A. Bressan. 2016. A Resource Based View of the Firm and Micro and Small Italian Wine Firms. International Journal of Wine Business Research 28(4): 349-368.

Anjaningrum, W. D. 2021. Integrasi Menuju Industri Kreatif yang Kuat dan Dinamis. Jurnal Ilmiah Bisnis Dan Ekonomi Asia 15(1): 30-40.

Anwar, J. dan S. Hasnu. 2016. Business Strategy and Firm Performance: a Multi-Industry Analysis. Journal of Strategy and Management 9(3): 361-382.

Apriadi, D. dan A. Y. Saputra. 2017. E- 
Commerce Berbasis Marketplace Dalam Upaya Mempersingkat Distribusi Penjualan Hasil Pertanian. Jurnal RESTI (Rekayasa Sistem dan Teknologi Informasi) 1(2): 131-136.

Aziz, N. N. A. dan S. Samad. 2016. Innovation and Competitive Advantage: Moderating Effects of Firm Age in Foods Manufacturing SMEs in Malaysia. Procedia Economics and Finance 35(October 2015): 256-266.

Badan Pusat Statistik. 2020. Statistik ECommerce 2020. Badan Pusat Statistik Katalog BPS: 8101004. Badan Pusat Statistik. Jakarta-Indonesia.

Banker, R. D., R. Mashruwala, dan A. Tripathy. 2014. Does a Differentiation Strategy Lead to More Sustainable Financial Performance than a Cost Leadership Strategy? Management Decision 52(5): 872-896.

Barney, J. 1991. Firm Resources and Sustained Competitive Advantage. Journal of Management 17(1): 99-120.

Barney, J., M. Wright, dan D. J. Ketchen Jr. 2001. The Resource based view of the firm: ten years after 1991. Journal of Managemen 27(6): 625-641.

Basry, A. dan E. M. Sari. 2018. Penggunaan Teknologi Informasi dan Komunikasi (TIK) pada Usaha Mikro, Kecil dan Menengah (UMKM). IKRA-ITH INFORMATIKA: Jurnal Komputer dan Informatika 2(3): 53-60.

Bouwman, H., S. Nikou, dan M. de Reuver. 2019. Digitalization, Business Models, and SMEs: How do Business Model Innovation Practices Improve Performance of Digitalizing SMEs? Telecommunications Policy 43(9): 101828.

Bulak, M. E. dan A. Turkyilmaz. 2014. Performance Assessment of Manufacturing SMEs: a Frontier Approach. Industrial Management and Data Systems 114(5): 797-816.

Burvill, S. M., D. J. Evans, dan H. Rowlands. 2018. Reconceptualising the Principles of Penrose's 1959. Theory and the Resource Based View of the Firm: The
Generation of a New Conceptual Framework. Journal of Small Business and Enterprise Development 25(6): 930-959.

Chi, M., J. Zhao, dan Y. Li. 2016. Digital Business Strategy and Firm Performance: the Mediation Effects of Ecollaboration Capability. WHICEB 2016 Proceedings. 58.

Databooks. 2017a. Berapa Pasar e-Commerce Indonesia? In Dkatadata.co.id. https:// databoks.katadata.co.id/datapublish/2017/0 8/16/berapa-pasar-e-commerce-indonesia.

Databooks. 2017b. Seberapa Siap Pengusaha Indonesia dengan Transformasi Digital? In Dkatadata.co.id. http://databoks.katadata.co.id/datapublish/2017/03/06/sebe rapa-siap-pengusaha-indonesia-dengantransformasi-digital.

Databooks. 2018. Media Digital Membunuh Media Konvensional? In Dkatadata.co.id. https://databoks.katadata.co.id/datapublish/ 2018/02/18/media-digital-membunuhmedia-konvensional.

Databooks. 2019a. 10 E-Commerce dengan Pengunjung Terbesar Kuartal III-2019. In Katadata.Co.Id. https://databoks. katadata.co.id/datapublish/2019/10/22/inila h-10-e-commerce-dengan-pengunjungterbesar.

Databooks. 2019b. Berapa Pengguna Media Sosial Indonesia? In Katadata.Co.Id. https://databoks.katadata.co.id/datapublish/ 2019/02/08/berapa-pengguna-media-sosialindonesia.

Databooks. 2020a. 10 Media Sosial yang Paling Sering Digunakan di Indonesia. In Dkatadata.co.id. https://databoks. katadata.co.id/dataublish/2020/02/26/10media-sosial-yang-paling-seringdigunakan-di-indonesia.

Databooks. 2020b. Masyarakat Paling Banyak Mengakses Informasi dari Media Sosial. In Dkadata.co.id.

Dewi, M. C. 2020. Pemanfaatan Teknologi bagi UMKM Selama Pandemi Covid-19. Jurnal Mozaik 12(2): 11-19.

Dhewanto, W., R, V. N. Rizqi, F. Yunita, S. Azzahra, dan D. Adrian. 2018. Internasionalisasi UKM, Usaha Kecil dan 
Mikro Menuju Pasar Global. Penerbit Andi. Yogyakarta.

Eniola, A. A. dan H. Entebang. 2015. SME Firm Performance-Financial Innovation and Challenges. Procedia-Social and Behavioral Sciences 195: 334-342.

Evangelista, P., R. Mogre, A. Perego, A. Raspagliesi, dan E. Sweeney. 2012. A Survey Based Analysis of IT Adoption and 3PLs' Performance. Supply Chain Management 17(2): 172-186.

Eze, N. M., S. F. Ayigbe, O. O. Eberechi, dan N. Jordan. 2015. Information and Communication Technology Applications in Small and Medium Scale Enterprises (SMEs) Funding in Nigeria: an Impact Assessment. International Journal of Finance and Accounting 4(5): 293-303.

Ezzi, S. W. 2016. Exploring the Characteristics of the E-commerce Marketplace in Saudi Arabia. International Journal of Economic Perspectives 10(4): 520.

Fathurrohman, Y. E. 2016. Peran Media Sosial Sebagai Ujung Tombak Pemasaran Bagi Usaha Mikro Kecil Menengah (UMKM). Prosiding Seminar Nasional Pembangunan Pertanian 53(9): 508-515.

Fitriati, R. 2015. Menguak Daya Saing UMKM Industri Kreatif. Yayasan Pustaka Obor Indonesia. Jakarta, Indonesia.

Ghobakhloo, M., D. A. Aranda, dan J. B. Amado. 2011. Adoption of E-commerce Applications in SMEs. Industrial Management \& Data Systems 111(8): 1238-1269.

Hadiati, S. 2016. Peran Struktur Pasar Dan Daya Saing Dalam Meningkatkan Kinerja UMKM Kerajinan Keramik. EKUITAS (Jurnal Ekonomi dan Keuangan) 20(3): 367-387.

Hardilawati, W. L. 2020. Strategi Bertahan UMKM di Tengah Pandemi Covid-19. Jurnal Akuntansi \& Ekonomika 10(1): 8999.

Hartini, S. 2013. Hubungan Orientasi Pasar, Strategi Bersaing, Kewirausahaan Korporasi dan Kinerja Perusahaan.
EKUITAS (Jurnal Ekonomi dan Keuangan) 17(1): 39-53.

Haryanto. 2014. Niat Adopsi Teknologi Informasi: Sebuah Kajian Empiris Online Business. EKUITAS (Jurnal Ekonomi dan Keuangan) 18(2): 165-180.

Haseeb, M., M. Lis, I. Haouas, dan L. W. W. Mihardjo. 2019. The Mediating Role of Business Strategies between Management Control Systems Package and Firms Stability: Evidence from SMEs in Malaysia. Sustainability (Switzerland) 11(17): 4705.

Hilman, H. dan N. Kaliappen. 2014. Do Cost Leadership Strategy and Process Innovation Influence the Performance of Malaysia Hotel Industry? Asian Social Science 10(10): 134-141.

Hutabarat, J. dan M. Huseini. 2012. Strategi Pendekatan Komprehensif dan Terintegrasi "Strategic Excellence" dan "Operational Excellence" Secara Simultan. Penerbit Universitas Indonesia (UI-Oress). Jakarta, Indonesia.

Ilmudeen, A. dan B. H. Malik. 2017. A Review of Information Technology Governance, Business Strategy and Information Technology Strategy. International Journal of Advanced Research 6(6): 120-129.

Johannessen, J., J. Olaisen, dan B. Olsen. 1999. Strategic Use of Information Technology for Increased Innovation and Performance. Information Management \& Computer Security 7(1): 5-22.

Khin, S. dan T. C. Ho. 2018. Digital Technology, Digital Capability and Organizational Performance: A Mediating Role of Digital Innovation. International Journal of Innovation Science 11(2): 177-195.

Kim, S. J., E. Maslowska, dan E. C. Malthouse. 2017. Understanding the Effects of Different Review Features on Purchase Probability. International Journal of Advertising 37(1): 29-53.

Kowo, S., O. Sabitu, dan G. Adegbite. 2018. Influence of Competitive Strategies on Corporate Performance of Small and 
Medium Enterprises: A Case From Nigeria. Agricultural and Resource Economics: International Scientific EJournal (4,№ 3): 14-33.

Liou, F. M. dan Y. C. Gao. 2011. Competitive Advantage in the Online Game Industry in Taiwan. Journal of Strategy and Management 4(2): 136-154.

Lockett, A., R. P. O'Shea, dan M. Wright. 2008. The Development of the ResourceBased View: Reflections from Birger Wernerfelt. Organization Studies 29(8-9): 1125-1141.

Madhani, P. M. 2010. Resource Based View (RBV) of Competitive Advantage: an Overview. Resource Based View: Concepts and Practices, Pankaj Madhani ed: 3-22.

Magretta, J. 2002. Why Business Models Matter. Harvard Business Review 80(5): 86-133.

Mary, O. E., U. E. Ifeanyi, dan O. Leonard. 2015. Information and Communication Technology and the Performance of Selected Small and Medium Enterprises in Onitsha Metropolis. International Journal of Development Research 5(11): 6057-6061.

Moeuf, A., R. Pellerin, S. Lamouri, S. Tamayo-Giraldo, dan R. Barbaray. 2018. The Industrial Management of SMEs in the Era of Industry 4.0. International Journal of Production Research 56(3): 1118-1136.

Nuvriasari, A., G. Wicaksono, dan S. Sumiyarsih. 2015. Peran Orientasi Pasar, Orientasi Kewirausahaan Dan Strategi Bersaing Terhadap Peningkatan Kinerja UKM. EKUITAS (Jurnal Ekonomi Dan Keuangan) 19(2): 241-259.

Olsen, T. dan I. Safdar. 2014. Research: Effects of Industrial Organization Perspective and Resource-Based View on Firm Performance: The Moderating Role of Industry Characteristics. Tesis. University of South-Eastern Norway. Kongsberg, Norway.

Piarna, R. dan F. Fathurohman. 2019. Adopsi E-Commerce Pada UMKM di Kota Subang Menggunakan Model Utaut.
Jurnal Ilmiah Ilmu dan Teknologi Rekayasa 2(1): 125-132.

Piercy, N. 2009. Positive Management of Marketing-Operations Relationships: the Case of an Internet Retail SME. Journal of Marketing Management 25(5-6): 551-570.

Porter, M. E. 1980. Competitive Strategy. The Free Press. New York.

Purwanto, D. 2011. Komunikasi Bisnis. PT. Gelora Aksara Pratama. Jakarta.

Rajapathirana, R. P. J. dan Y. Hui. 2017. Relationship between Innovation Capability, Innovation Type, and Firm Performance. Journal of Innovation $\mathcal{E}$ Knowledge 3(1): 44-55.

Ramadhany, B. R. dan O. K. Pritasari. 2020. Pemanfaatan Media Sosial Sebagai Media Pemasaran Terhadap Produk Nurayya Sampo Dandruff Tanpa Kandungan Sls. Jurnal Tata Rias 09(2): 51-59.

Raymond, L. dan F. Bergeron. 2008. Enabling the Business Strategy of SMEs through E-Business Capabilities. Industrial Management \& Data Systems 108(5): 577595.

Sayekti, N. W. 2014. Jaminan Produk Halal dalam Perspektif Kelembagaan. Jurnal Ekonomi dan Kebijakan Publik 5(2): 193209.

Scupola, A. 2009. SMEs e-Commerce Adoption: Perspectives from Denmark and Australia. Journal of Enterprise Information Management 22(1/2): 152166.

Suardhika, I. N. 2012. Model Integrasi dalam Resources-Based View untuk Penerapan Strategi Bersaing dan Pencapaian Kinerja Usaha. Ekuitas: Jurnal Ekonomi dan Keuangan 16(1): 63-83.

Sugiyono. 2018. Metode Penelitian Kuantitatif. Alfabeta. Bandung.

Supratiwi, W. dan D. Agustia. 2020. Organizational Transformation: Memediasi Pengaruh Investasi Teknologi Informasi Terhadap Kinerja Organisasi Pada Pemerintah Daerah di Indonesia. EKUITAS (Jurnal Ekonomi dan Keuangan) 
3(3): 403-422.

Tambunan, T. T. H. 2017. Usaha Mikro, Kecil, dan Menengah. Ghalia Indonesia. Surabaya.

Tarutè, A. dan R. Gatautis. 2014. ICT Impact on SMEs Performance. Procedia-Social and Behavioral Sciences 110: 1218-1225.

Teeratansirikool, L., S. Siengthai, Y. Badir, dan C. Charoenngam. 2013. Competitive Strategies and Firm Performance: the Mediating Role of Performance Measurement. International Journal of Productivity and Performance Management 62(2): 168-184.

Theo, W. H. dan W. Tim. 2005. The Impact of IT on Competitive Advantage: a Microeconomic Approach to Making the Resource Based View Explicit. Proceedings 13th European Conference on Information Systems (ECIS) 2005.

Valdez-Juárez, L. E., D. García-Pérez-deLema, dan G. Maldonado-Guzmán. 2018. ICT and KM, Drivers of Innovation and Profitability in SMEs. Journal of Information $\mathcal{E}$ Knowledge Management 17(01): 1850007.

Wang, H. L. 2013. Theories for Competitive Advantage. Faculty of Business - Papers (Archive) 408: 33-43.

Wen, X., D. Quacoe, A. Dodor, D. Quacoe, dan I. A. Bediako. 2018. Financial Performance of Listed SMEs: A Comparative Analysis between China and America. Journal of Small Business and Entrepreneurship Development 6(1): 48-58.

Wernerfelt, B. 1984. A Resource-Based View of the Firm. Strategic Management Journal 5: 171-180.

Wilantara, R. F. dan Susilawati. 2016. Strategi $\mathcal{E}$ kebijakan Pengembangan UMKM; Upaya Meningkatkan Daya Saing UMKM Nasional di ERA MEA. Refika Aditama. Bandung, Indonesia.
Yoshikuni, A. C. dan A. L. Albertin. 2018. Effects of Strategic Information Systems on Competitive Strategy and Performance. International Journal of Productivity and Performance Management 67(9): 2018-2045.

Yuliana, O. Y. 2000. Penggunaan Teknologi Internet. Jurnal Akuntansi \& Keuangan 2(1): 36-52.

Yuliansyah, Y., H. G. Rammal, dan E. Rose 2016. Business Strategy and Performance in Indonesia's Service Sector. Journal of Asia Business Studies 10(2): 164-182.

Yunis, M., A. Tarhini, dan A. Kassar. 2018. The Role of ICT and Innovation in Enhancing Organizational Performance: The Catalysing Effect of Corporate Entrepreneurship. Journal of Business Research 88(June 2017): 344356.

Yuwana, S. I. P. 2020. Coronanomics: Strategi Revitalisasi UMKM Menggunakan Teknologi Digital di Tengah Pandemi Covid-19. Journal of Technopreneurship on Economics and Business Review 2(1): 5868.

Zailani, S., K. Kanapathy, M. Iranmanesh, dan M. Tieman. 2015. Drivers of Halal Orientation Strategy among Halal Food Firms. British Food Journal 117(8): 21432160.

Zainurrafiqi, Z. dan R. Rachmawati. 2019. Pengaruh Etika Bisnis, Faktor Kontingensi dan Tingkat Penggunaan Internet terhadap Daya Saing. EKUITAS (Jurnal Ekonomi dan Keuangan) 2(4): 550-571.

Zhang, M. dan P. S. Tansuhaj. 2007. Organizational Culture, Information Technology Capability, and Performance: The Case of Born Global Firms. Multinational Business Review 15(3): 4378. 